\title{
Whites and Browns: A Contrastive Study of Metadiscourse in English Newspaper Editorials
}

\author{
Muhammad Imtiaz Shahid, ${ }^{1}$ Hafiz Muhammad Qasim, ${ }^{2 *}$ \\ Muhammad Hasnain ${ }^{3}$ \\ 1, 2,3 Department of Applied Linguistics, Faculty of Social Sciences, Government College \\ University Faisalabad, Punjab 38000, Pakistan \\ *) Corresponding Author \\ Email: muhammadqasim@gcuf.edu.pk \\ DOI: $10.18326 /$ rgt.v14i1.25-42
}

Submission Track:

Received: 07-10-2020

Final Revision: 01-04-2021

Available Online: 01-06-2021

Copyright (C) 2021 Authors

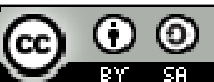

This work is licensed under a Creative Commons Attribution-ShareAlike 4.0 International License.

\begin{abstract}
Metadiscourse is an interesting field of inquiry which is believed to play a vital role in organizing and producing persuasive writing. It is a set of linguistic devices used to communicate attitudes and mark the structural properties of a text. The study aimed to investigate whether native and non-native varieties of English varieties are similar or different from each other from the perspective of interactional meta-discourse markers. The study as contrastive rhetoric research scrutinized a corpus of 900 newspapers editorials (450 written in native English newspapers and 450 written in non-native English newspapers). Editorials were culled from 15 native English newspapers belonging to three native English countries, England, America and New Zealand, and 15 non-native English newspapers belonging to three non-native English countries, Pakistan, India and Sri Lanka. Based on the model of metadiscourse given by Hyland (2005), interactional metadiscoursive resources were analyzed. The frequencies of interactional metadiscourse markers in both native and nonnative varieties were counted and compared with each other. The results disclosed that there were worth-pointing differences between the native and non-native English editorialists in the use of interactional metadiscourse markers. Two different varieties of English editorials showed variations particularly in the use of hedging and self-mention markers. On the whole, findings suggested that the use of interactionalmetadiscourse markers in native English editorials were more frequent than those in non-native English editorials which made their writings more appealing and convincing context.
\end{abstract}

Keywords: metadiscourse; native; non-native; newspaper; editorials 


\section{INTRODUCTION}

Language is a part of society (Moreno, 1997) and society is inextricably linked to the culture which means that a piece of writing is a reflection of culture (Moreno, 1997). Writings emerge out of language. That is why language and writing are said to be a cultural phenomenon (Kaplan, 1996). The result of such a cultural phenomenon is that every society has its language and rhetorical norms and traditions (Connor, 1996). Therefore, it can be pointed out that usage of metadiscourse may vary across different cultures, languages and communities. The social view of written communication suggests that the text is a site where the writer and the reader are engaged in dialogic interactions based on shared interpretive practices. Fowler (1991) considers the author and the reader to be co-creators, discussing the nature and importance of language based on more or less shared knowledge of the world, society and language.

The term "metadiscourse" was coined by Harris in 1959 to understand the system of language. Metadiscourse is an essential tool for creating links among texts and their contexts in which they are used because metadiscourse directs readers' attention towards certain forms of engagements and interactions. It brings into light the dialogic role of discourse by revealing authors' understanding through the way he/she addresses readers and their needs. It is a way of looking at language use based on the fact that, as we speak or write, we monitor the possible responses of others, making decisions about the kind of effects we are having on our listeners or readers, and adjusting our language to best achieve our purposes.

Metadiscourse is one of the main tools that allows an author to create the meaning of a text and its social impacts on society and its readers (Siddique, Mahmood \& Iqbal, 2018). It includes works by authors and their readers on mutual understanding and engagement (Hyland, 2005). Authors use the Methodiscourse to demonstrate the appropriate professional personality to guide and motivate their readers because the metadiscourse is an important part of persuasive writing (Hyland, 1998a). Therefore, persuasive writing can be considered a major object for metadiscourse research. In this regard, Ansary and Babaii (2009) point out that editorials play an important part in the design of readers' ideology and position of their readers because editorialists by designing the design of their writings design the position and ideology of their readers. Editorialist may inculcate the ideology for which he is working. 
An editorialist may persuade, motivate, change, and even manipulate others (Milne, 2008). For this purpose, editorialists use metadiscourse as a strategy of manipulation and persuasion (Siddique, Mahmood \& Iqbal, 2018). Ansary and Babaii (2009) pointed out that editorials of the newspapers are a significant and interesting genre for the investigation of linguistic variations among different cultures because editorials are very much representative day to day and cultural issues. As a result, a cross-linguistic study on the organization of metadiscourse would yield interesting results in newspapers' editorials.

As stated earlier, the current study has used Interpersonal Metadiscourse Model given by Hayland in 2005 which is divided into two categories, interactional category and interactive category. Both interactional and interactive categories of the model are given in Figure 1 and 2. Different markers of the model are identified and categorized based on Hyland's (2005) classification of interactional category.

Studying metadiscourse is a well-established research field. Many researchers have conducted research using Interpersonal metadiscourse model. Different markers of metadiscourse have been identified and examined in several ways by different researchers in a number of contexts, including science popularizations, textbooks (Crismore, 1984; Hyland, 1999, 2000), student writing (Crismore, Markkanen \& Steffensen, 1993), research articles (Mauranen, 1993; Valero, 1996; Moreno, 1997; Hyland, 1998a, 1998b, 2000, 2001; Mur-Dueñas, 2011), and advertisement (Olivera, Sacristán, Baño \& Fernández, 2001). But surprisingly little attention has been given to the genre of newspaper opinion and editorials.

Contrastive studies are more important than a normal investigation of metadiscourse because they analyse two fields and by comparing them give results. They are more important for the understanding of cultural and linguistic variations (Mina \& Biria, 2017). Bhatia (1993) pointed out that there are a lot of genres within one newspaper such as sports reports, opinions, editorials, news reports, and headlines etc. which make the language of a newspaper attractive. In such a wide variety of genres, an editorial is the most significant and appropriate for the analysis of metadiscourse because editorials hold writers' opinion about political and public issues (Mina \& Biria, 2017). 


\section{Figure 1}

Hyland's Model of Interpersonal Metadiscourse (2005: 49)

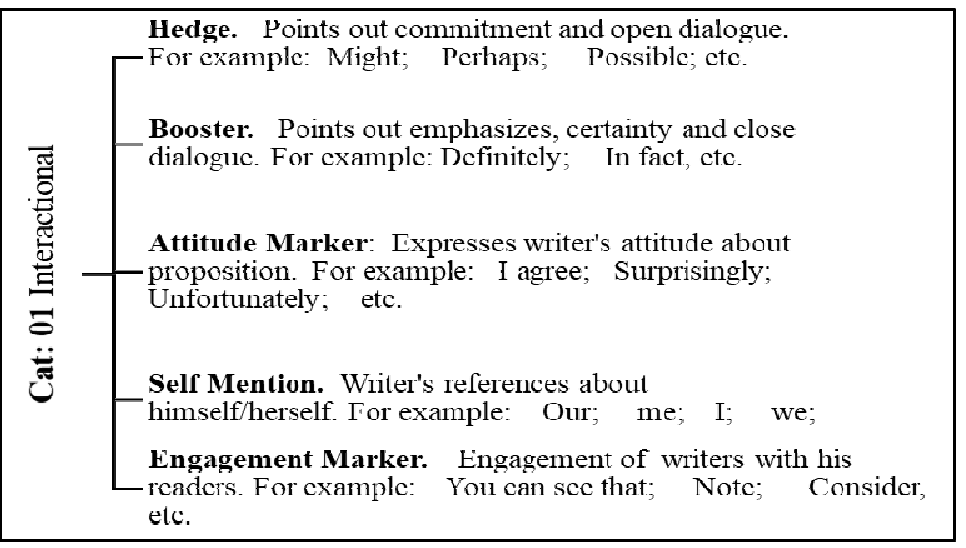

Figure 2

Hyland's Model of Interpersonal Metadiscourse (2005: 49)

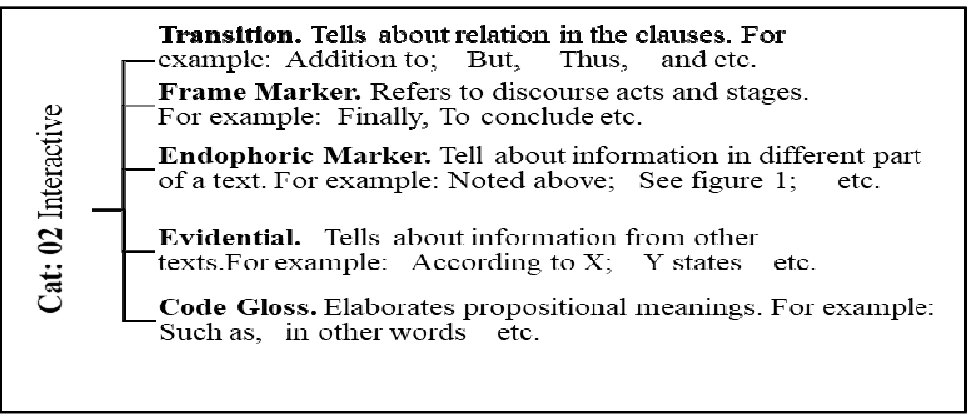

A contrastive study of Persian and English editorials was conducted by Kuhi and Mojood in 2012 based on Hyland's model (2005). It showed very interesting results. The results disclosed that English and Persian editorials were different from each other because of their linguistic and cultural variations. The study pointed out that attitude markers and interactional markers were very prominent in newspapers editorials. On the whole, the results of the research commended that metadiscourse had a conclusive role in the organization of persuasive techniques in newspapers commentaries. 
Following this tradition of contrastive research a cross-linguistic study conducted by Shahid, Qasim and Hasnain (2020). It analyzed English and Urdu newspaper editorials by using Hyland's (2005) model. The results of the study showed that both the languages were different from each other in the use of metadiscourse markers. On the whole, the study concluded that the use of interactional metadiscourse was a predominant category and attitude marker was a predominant feature in both groups.

Although different researches were conducted in the past by the different researchers in different genres there is a complete lack of contrastive research on newspaper editorials. There is a dire need of metadiscourse research in this field. That is why the present study intended to investigate interactional metadiscourse markers in native and non-native English editorials.

\section{Objectives and Hypothesis}

The present research is designed to find out whether the native and nonnative English varieties are similar or different from one another. It is also designed to investigate the differences and similarities between native and nonnative English editorialist in the use of interactional metadiscourse marker. It tries to find out whether both groups of editorialists use similar types of markers or not. It is based on premise that English editorialists are good at using metadiscourse markers in their editorials than non-native ones which make their writing more appealing and convincing.

\section{RESEARCH METHOD}

\section{Data Collection}

Two different corpora were built based on the selection of 900 ( 450 written in Native English newspaper and 450 written in Pakistani English newspaper) editorials taken from native newspapers and non-native English newspapers. To mitigate the diachronic effects on the selected sample, only editorials published in March, April and May (2019) were included in the sample. The purpose of taking data from native and non-native English editorial was that the researcher assumed native English editorialists were better in English and using metadiscourse markers in their editorials than non-native ones. Table 1 and 2 shed more light on the selection procedure of data. Links of newspapers were given in the reference list under the heading of Newspaper. 
Table 1

A Summary of the Data Sample Taken from Native English Editorials

\begin{tabular}{cllll}
\hline Sr. No & Name of Newspaper & Country & $\begin{array}{l}\text { No of } \\
\text { Editorials }\end{array}$ & Words \\
\hline 01 & The New York Time & America & 30 & 13437 \\
02 & Washington Post & 30 & 15882 \\
03 & Afro American & 30 & 19428 \\
04 & State of Arizona & 30 & 21372 \\
05 & USA Today & England & 30 & 17610 \\
06 & The Guardian & 30 & 23538 \\
07 & City A.M. & 30 & 15183 \\
08 & Lancashire Evening Post & & 30 & 14133 \\
09 & Yorkshire Post & 30 & 18504 \\
10 & The Bolton News & 30 & 25788 \\
11 & The New Zealand Herald & New Zealand & 30 & 18489 \\
12 & The Press & 30 & 24507 \\
13 & The Northern Advocate & & 30 & 21246 \\
14 & The Southland Times & & 30 & 15282 \\
15 & The Nelson Mail & 30 & 13737 \\
\hline
\end{tabular}

Table 2

A Summary of the Data Sample Taken from Non-native English Editorials

\begin{tabular}{cllll}
\hline Sr. No & Name of Newspaper & Country & $\begin{array}{l}\text { No of } \\
\text { Editorials }\end{array}$ & Words \\
\hline 01 & Dawn & Pakistan & 30 & 19701 \\
02 & The News International & & 30 & 15147 \\
03 & Pakistan Observer & & 30 & 21270 \\
04 & The Nation & & 30 & 17967 \\
05 & Daily Pakistan & India & 30 & 26763 \\
06 & Hindustan Times & & 30 & 21291 \\
07 & Times of India & & 30 & 13707 \\
08 & The Tribune & 30 & 21291 \\
09 & The Hindu & 30 & 16935 \\
10 & The New India Express & Sri Lanka & 30 & 16296 \\
11 & Daily News & & 30 & 19623 \\
12 & The Daily Mirror & & 30 & 14163 \\
13 & Sunday Observer & & 30 & 14724 \\
14 & The Island & & 30 & 19734 \\
15 & Daily FT & & 450 & 279348 \\
\hline
\end{tabular}




\section{Data Analysis}

Data analysis was based on Hyland model of metadiscourse. As already mentioned, Hyland model of metadiscourse was divided into two categories Interactive and Interpersonal (Hyland, 2005) but, in this research, only one category of this model, interactional, was investigated in both native and nonnative English editorials. It was subdivided into five major categories. For subcategories, the description is given in Table 3. Then Frequencies of both groups were investigated using Antconc 3.5.7. Frequencies of different categories were calculated from both corpus and after getting the total of all markers, the results were compared with one another.

\section{Table 3}

Interactional Metadiscourse Model (Hyland, 2005)

\begin{tabular}{|c|c|c|}
\hline Main Categories & Subcategories & Examples \\
\hline Hedges & $\begin{array}{l}\text { Epistemic verbs } \\
\text { Probability adverbs } \\
\text { Epistemic Expressions } \\
\text { Intensifier adverbs }\end{array}$ & $\begin{array}{l}\text { May, can, would etc. } \\
\text { About, probably, perhaps etc. } \\
\text { Most, probable, typical etc. } \\
\text { Always, never, actually etc. }\end{array}$ \\
\hline Booster & $\begin{array}{l}\text { Intensifier adjectives } \\
\text { Intensifier verbs } \\
\text { Attitude verbs }\end{array}$ & $\begin{array}{l}\text { True, obvious, clear etc. } \\
\text { Prove, think, decide etc. } \\
\text { Tend, propose, suggest etc. }\end{array}$ \\
\hline Attitude Markers & $\begin{array}{l}\text { Attitudinal adverbs } \\
\text { Attitudinal adjectives }\end{array}$ & $\begin{array}{l}\text { Fortunately, unfortunately, } \\
\text { etc. } \\
\text { Inappropriate, usual, unusual } \\
\text { etc. }\end{array}$ \\
\hline Self-mention & $\begin{array}{l}1^{\text {st }} \text { person pronoun } \\
\text { Reader pronoun }\end{array}$ & $\begin{array}{l}\text { We, me, I etc. } \\
\text { You, one's, your etc. }\end{array}$ \\
\hline $\begin{array}{l}\text { Engagement } \\
\text { Markers }\end{array}$ & $\begin{array}{l}\text { Interjection } \\
\text { Directive imperatives } \\
\text { Obligation modals }\end{array}$ & $\begin{array}{l}\text { By the way etc. } \\
\text { Note, note that etc. } \\
\text { Do not, need to, must to etc. }\end{array}$ \\
\hline
\end{tabular}

\section{RESULTS \& DISCUSSION}

Based on the results in Table 4, the frequency and percentage of boosters, Engagement markers and self- mentions in the native English newspapers editorials were significantly more than their use in non-native English newspapers editorials. Also, there was a significant difference in applying hedges and attitude markers between the two groups. In subsequent categories 
of hedges, a significant difference between the two groups was observed. Nonnative English editorialists applied epistemic verbs, probability adverbs, and epistemic expressions in their editorials more frequently than the editorialists of native English newspapers.

\section{Table 4}

Frequencies of Interactional Metadiscourse Markers in the Corpus

\begin{tabular}{|c|c|c|c|c|}
\hline \multirow{2}{*}{ Interactional Markers } & \multicolumn{2}{|c|}{ Whites Editorials } & \multicolumn{2}{|c|}{ Browns Editorials } \\
\hline & $\mathrm{F}$ & $* \mathrm{P}$ & $\mathrm{F}$ & $P$ \\
\hline \multicolumn{5}{|l|}{ Hedges } \\
\hline Epistemic verbs & 3283 & 21.68 & 4368 & 31.65 \\
\hline Probability adverbs & 1347 & 8.89 & 1002 & 7.26 \\
\hline Epistemic Expressions & 390 & 2.57 & 522 & 3.78 \\
\hline Total & 5020 & 33.15 & 5892 & 42.70 \\
\hline \multicolumn{5}{|l|}{ Boosters } \\
\hline Intensifier adverbs & 984 & 6.50 & 567 & 4.10 \\
\hline Intensifier adjectives & 354 & 2.33 & 375 & 2.71 \\
\hline Intensifier verbs & 807 & 5.33 & 627 & 4.54 \\
\hline Total & 2145 & 14.16 & 1569 & 11.37 \\
\hline \multicolumn{5}{|l|}{ Attitude markers } \\
\hline Attitude verbs & 837 & 5.52 & 738 & 5.34 \\
\hline Attitudinal adverbs & 63 & 0.41 & 150 & 1.08 \\
\hline Attitudinal adjectives & 225 & 1.48 & 264 & 1.91 \\
\hline Total & 1125 & 7.43 & 1152 & 8.34 \\
\hline Self-mentions & 4827 & 31.88 & 2418 & 17.52 \\
\hline \multicolumn{5}{|l|}{ Engagement markers } \\
\hline Reader pronoun & 1560 & 10.30 & 513 & 3.71 \\
\hline Interjection & 03 & 0.01 & 03 & 0.02 \\
\hline Directive imperatives & 75 & 0.49 & 114 & 0.82 \\
\hline Obligation modals & 1509 & 9.96 & 2136 & 15.48 \\
\hline Total & 3147 & 20.78 & 2766 & 20.04 \\
\hline Grand Total & 15138 & 100 & 13797 & 100 \\
\hline
\end{tabular}

Note: ${ }^{*}=\mathrm{F} \times 100 \div \mathrm{T}=\%$, F: Frequency, P: Percentage

A significant difference was observed in applying intensifier adverbs and verbs. Native editorialists used more adverbs than non-native editorialists. In addition, no significant difference was observed in applying intensifier adjectives in two groups. 
Whites and Browns: A Contrastive Study of Metadiscourse ....

Table 5

The Use of Hedges in Newspapers Editorials

\begin{tabular}{|c|c|c|c|c|c|}
\hline \multirow{2}{*}{ Hedges } & \multirow{2}{*}{ Words } & \multicolumn{2}{|c|}{ White Editorials } & \multicolumn{2}{|c|}{ Brown Editorials } \\
\hline & & $\mathrm{F}$ & $\mathrm{P}$ & $\mathrm{F}$ & $\mathrm{P}$ \\
\hline \multirow[t]{21}{*}{ Epistemic verb } & May & 318 & 6.33 & 402 & 6.82 \\
\hline & Might & 141 & 2.80 & 93 & 1.57 \\
\hline & Can & 684 & 13.62 & 738 & 12.52 \\
\hline & Could & 342 & 8.42 & 528 & 8.96 \\
\hline & Could not & 36 & 0.71 & 81 & 1.37 \\
\hline & Would & 696 & 13.86 & 723 & 12.27 \\
\hline & Would not & 24 & 0.47 & 57 & 0.96 \\
\hline & Should & 294 & 5.85 & 648 & 10.99 \\
\hline & Should not & 15 & 0.29 & 87 & 1.47 \\
\hline & Need & 219 & 4.36 & 288 & 4.88 \\
\hline & Must & 195 & 3.88 & 339 & 5.75 \\
\hline & Seem & 48 & 0.95 & 69 & 1.71 \\
\hline & Estimate & 03 & 0.05 & 06 & 0.10 \\
\hline & Argue & 24 & 0.47 & 09 & 0.15 \\
\hline & Clear & 150 & 2.98 & 144 & 2.44 \\
\hline & Claim & 54 & 1.07 & 66 & 1.12 \\
\hline & Indicate & 09 & 0.17 & 18 & 0.30 \\
\hline & Tend to & 12 & 0.23 & 09 & 0.15 \\
\hline & Suggest & 12 & 0.23 & 36 & 0.61 \\
\hline & Suppose & 06 & 0.11 & 00 & 000 \\
\hline & Assume & 00 & 000 & 27 & 0.45 \\
\hline \multirow{13}{*}{$\begin{array}{l}\text { Probability } \\
\text { adverbs }\end{array}$} & About & 996 & 19.84 & 588 & 9.97 \\
\hline & Probably & 48 & 0.95 & 27 & 0.45 \\
\hline & Perhaps & 75 & 1.49 & 108 & 1.83 \\
\hline & Maybe & 36 & 0.71 & 00 & 00 \\
\hline & Possibly & 24 & 0.47 & 00 & 00 \\
\hline & Almost & 99 & 1.97 & 144 & 2.44 \\
\hline & Relatively & 06 & 0.11 & 00 & 00 \\
\hline & Fairly & 06 & 0.11 & 06 & 0.10 \\
\hline & Mainly & 03 & 0.05 & 36 & 0.61 \\
\hline & Frequently & 09 & 0.17 & 12 & 0.20 \\
\hline & Sometimes & 21 & 0.41 & 27 & 0.45 \\
\hline & Somewhat & 09 & 0.17 & 27 & 0.45 \\
\hline & Generally & 15 & 0.29 & 27 & 0.45 \\
\hline \multirow{7}{*}{$\begin{array}{l}\text { Epistemic } \\
\text { expressions }\end{array}$} & Most & 288 & 5.73 & 414 & 7.06 \\
\hline & Probable & 03 & 0.05 & 00 & 000 \\
\hline & Possible & 78 & 1.55 & 102 & 1.47 \\
\hline & Apparent & 09 & 0.17 & 00 & 000 \\
\hline & Uncertain & 03 & 0.05 & 03 & 0.05 \\
\hline & Typical & 06 & 0.11 & 00 & 000 \\
\hline & In most cases & 03 & 0.05 & 03 & 0.05 \\
\hline Total & & 5019 & 100 & 5892 & 100 \\
\hline
\end{tabular}

Note: F: Frequency, P: Percentage 
According to the results, hedges were used in the non-native English editorials more than the native English editorials. They were in higher sequence, and all subtypes of this maker were used more frequently in the non-native English editorials as compared to the native ones.

\section{Table 6}

The Use of Boosters in Newspapers Editorials

\begin{tabular}{|c|c|c|c|c|c|}
\hline \multirow{2}{*}{ Booster } & \multirow{2}{*}{ Words } & \multicolumn{2}{|c|}{ White Editorials } & \multicolumn{2}{|c|}{ Brown Editorials } \\
\hline & & $\mathrm{F}$ & $\mathrm{P}$ & $\mathrm{F}$ & $\mathrm{P}$ \\
\hline \multirow[t]{12}{*}{ Intensifier adverbs } & Certainly & 45 & 2.09 & 57 & 3.56 \\
\hline & Really & 168 & 7.83 & 42 & 2.62 \\
\hline & Undoubtedly & 00 & 0.00 & 06 & 0.37 \\
\hline & Always & 189 & 8.81 & 81 & 5.06 \\
\hline & Never & 156 & 7.27 & 135 & 8.44 \\
\hline & Definitely & 18 & 0.83 & 15 & 0.93 \\
\hline & Obviously & 21 & 0.97 & 27 & 1.68 \\
\hline & Clearly & 84 & 3.91 & 45 & 2.81 \\
\hline & Totally & 18 & 0.83 & 18 & 1.12 \\
\hline & In fact & 69 & 3.21 & 69 & 4.31 \\
\hline & Of course & 99 & 4.61 & 48 & 03 \\
\hline & Actually & 117 & 5.45 & 24 & 1.50 \\
\hline \multirow[t]{7}{*}{ Intensifier adjectives } & True & 111 & 5.17 & 75 & 4.69 \\
\hline & Certain & 45 & 2.09 & 81 & 5.06 \\
\hline & It is clear that & 09 & 0.41 & 18 & 1.12 \\
\hline & Obvious & 21 & 0.97 & 27 & 1.68 \\
\hline & Undeniable & 12 & 0.55 & 06 & 0.37 \\
\hline & Clear & 150 & 6.99 & 144 & 09 \\
\hline & Evident & 06 & 0.27 & 24 & 1.50 \\
\hline \multirow[t]{9}{*}{ Intensifier verbs } & Demonstrate & 12 & 0.55 & 12 & 0.75 \\
\hline & Indicate & 09 & 0.41 & 18 & 1.12 \\
\hline & Show & 108 & 5.03 & 111 & 6.94 \\
\hline & Prove & 27 & 1.25 & 30 & 1.87 \\
\hline & Think & 153 & 7.13 & 66 & 4.12 \\
\hline & Decide & 24 & 1.11 & 33 & 2.06 \\
\hline & Know & 276 & 12.86 & 147 & 9.19 \\
\hline & Find & 87 & 4.05 & 135 & 8.44 \\
\hline & ${ }^{*}$ Found & 111 & 5.17 & 75 & 4.69 \\
\hline Total & & 2145 & 100 & 1599 & 100 \\
\hline
\end{tabular}

Note: ${ }^{*}=($ Siddique, Mahmood \& Iqbal, 2018), F: Frequency, P: Percentage

Based on the results in table 6, there was a significant difference between native and non-native editorialists. Boosters in the native English editorials were applied more than the non-native editorials of English. In the subcategory 
of intensifier adverbs, they were used more frequently in the native English editorials compared to the non-native editorials.

\section{Table 7}

The Use of Attitude Markers in Newspapers Editorials

\begin{tabular}{|c|c|c|c|c|c|}
\hline \multirow{2}{*}{ Attitude Marker } & \multirow{2}{*}{ Words } & \multicolumn{2}{|c|}{ White Editorials } & \multicolumn{2}{|c|}{ Brown Editorials } \\
\hline & & $\mathrm{F}$ & $\mathrm{P}$ & $\mathrm{F}$ & $\mathrm{P}$ \\
\hline \multirow[t]{17}{*}{ Attitude verbs } & Feel/felt & $132+60=192$ & 17.06 & $27+33=57$ & 5.20 \\
\hline & Believe/believed & $102+60=162$ & 14.4 & $48+54=102$ & 8.85 \\
\hline & *Think/thought & $153+78=231$ & 20.53 & $66+87=153$ & 13.2 \\
\hline & Presume/Expect & $48+06=54$ & 4.8 & 15 & 1.30 \\
\hline & Consider & 39 & 3.46 & 48 & 4.16 \\
\hline & Appear & 09 & 0.8 & 57 & 4.94 \\
\hline & Sound & 27 & 2.4 & 54 & 4.68 \\
\hline & Notice & 09 & 0.8 & 60 & 5.20 \\
\hline & Sense & 48 & 4.53 & 93 & 8.07 \\
\hline & Suppose & 06 & 0.53 & 00 & 000 \\
\hline & Predict & 00 & 000 & 03 & 0.26 \\
\hline & Estimate & 03 & 0.26 & 06 & 0.52 \\
\hline & Tend & 12 & 1.06 & 09 & 0.78 \\
\hline & Propose & 03 & 0.26 & 03 & 0.26 \\
\hline & Suggest & 12 & 1.06 & 36 & 3.12 \\
\hline & Agree & 27 & 2.4 & 21 & 1.82 \\
\hline & Prefer & 00 & 000 & 18 & 1.56 \\
\hline \multirow{5}{*}{$\begin{array}{l}\text { Attitudinal } \\
\text { adverbs }\end{array}$} & Usually & 06 & 0.53 & 24 & 2.08 \\
\hline & Importantly & 15 & 1.33 & 21 & 1.82 \\
\hline & Significantly & 09 & 0.8 & 39 & 3.38 \\
\hline & Unfortunately & 27 & 2.4 & 60 & 5.20 \\
\hline & Fortunately & 06 & 0.53 & 06 & 0.52 \\
\hline \multirow{10}{*}{$\begin{array}{l}\text { Attitudinal } \\
\text { adjectives }\end{array}$} & Essential & 12 & 1.06 & 27 & 2.34 \\
\hline & Important & 120 & 10.66 & 150 & 13.0 \\
\hline & Interesting & 21 & 1.86 & 15 & 1.30 \\
\hline & Usual & 24 & 2.13 & 09 & 0.78 \\
\hline & Unusual & 15 & 1.33 & 15 & 1.30 \\
\hline & Remarkable & 12 & 1.06 & 12 & 1.04 \\
\hline & Desirable & 00 & 000 & 03 & 0.26 \\
\hline & Appropriate & 12 & 1.06 & 24 & 2.08 \\
\hline & Inappropriate & 03 & 0.26 & 03 & 0.26 \\
\hline & Understandable & 06 & 0.53 & 06 & 0.52 \\
\hline Total & & 1125 & 100 & 1152 & 100 \\
\hline
\end{tabular}

Note: ${ }^{*}=($ Siddique, Mahmood \& Iqbal, 2018), F: Frequency, P: Percentage

Here in Table 7, there was no clear difference observed between native and non-native editorialists. The frequency of attitude markers in both varieties is almost the same. Native and non-native editorialists used almost attitude markers with the same frequency. 
M. I. Shahid, H. M. Qasim, M. Hasnain

\section{Table 8}

The Use of Self-mention in Newspapers Editorials

\begin{tabular}{llllll}
\hline \multirow{2}{*}{ Self-mention } & Words & \multicolumn{2}{c}{ White Editorials } & \multicolumn{2}{c}{ Brown Editorials } \\
& & F & P & F & P \\
\hline \multirow{2}{*}{$1^{\text {st }}$ person Pronoun } & We & 1602 & 33.18 & 798 & 33 \\
& Our & 750 & 15.53 & 462 & 19.10 \\
& *The author & 09 & 0.18 & 15 & 0.62 \\
& I & 1758 & 36.42 & 429 & 17.74 \\
& Mine & 15 & 0.31 & 15 & 0.62 \\
& The writer & 03 & 0.06 & 93 & 3.84 \\
& Us & 465 & 9.63 & 522 & 21.58 \\
& Me & 225 & 4.66 & 84 & 3.47 \\
\hline \multirow{2}{*}{ Total } & & 4827 & 100 & 2418 & 100 \\
\hline
\end{tabular}

Note: ${ }^{*}=($ Siddique, Mahmood \& Iqbal, 2018), F: Frequency, P: Percentage

There was a clear difference in both groups as it can be seen from the above-mentioned table. Self-mentions were used more in native English editorials compared to non-native English editorials. The highest difference between native and non-native was found in self-mention we.

\section{Table 9}

The Use of Engagement Markers in Newspaper Editorials

\begin{tabular}{llllll}
\hline \multirow{2}{*}{$\begin{array}{l}\text { Engagement } \\
\text { Marker }\end{array}$} & Words & \multicolumn{2}{c}{ White Editorials } & \multicolumn{2}{c}{ Brown Editorials } \\
& & $\mathrm{F}$ & $\mathrm{P}$ & $\mathrm{F}$ & $\mathrm{P}$ \\
\hline \multirow{2}{*}{ Reader pronoun } & You & 1221 & 38.79 & 384 & 13.88 \\
& Your & 324 & 10.29 & 123 & 4.46 \\
& Yourself & 15 & 0.47 & 06 & 0.21 \\
& One's & 00 & 000 & 00 & 000 \\
Interjection & By the way & 03 & 0.09 & 03 & 0.10 \\
Directive & Note that & 03 & 0.09 & 27 & 0.97 \\
imperatives & Consider & 39 & 1.23 & 48 & 1.73 \\
& Note & 18 & 0.57 & 39 & 1.40 \\
& Think about & 15 & 0.47 & 00 & 000 \\
Obligation modals & Do not & 48 & 1.71 & 108 & 3.90 \\
& Have to & 126 & 4.00 & 102 & 3.68 \\
& Need to & 120 & 3.81 & 159 & 5.74 \\
& Must & 195 & 6.19 & 339 & 12.25 \\
& Should & 294 & 9.34 & 648 & 23.42 \\
& Would & 696 & 22.11 & 723 & 26.41 \\
& Wouldn't & 24 & 0.76 & 57 & 2.06 \\
\hline Total & & 3147 & 100 & 2766 & 100 \\
\hline
\end{tabular}

Note: F: Frequency, P: Percentage 
According to Table 9, reader pronoun and obligations were used more frequently in native English editorials than in the non-native ones. But overall there was not much difference in the two groups.

On the whole, the findings of the study have pointed out that both groups of editorialists used interactional metadiscourse indicators in their editorials which show that they were conscious of the momentous part of metadiscourse markers in persuasion and manipulation (Hyland, 2005). Together with native and non-native newspaper, editorialists used metadiscourse markers to construct, organize and to evaluate the contents of the text. Editorialists of both native and non-native English are different at different levels of interactional metadiscourse. Editorialists in the two different varsities (native and nonnative) might have diverse approaches in consuming certain subtypes of metadiscourse because of their cultural modifications.

The interactional metadiscourse is a resource of logical, persuasive and manipulative varieties (Hyland, 2005), so, it can be found very frequently and commonly in the newspaper editorials. Dafouz (2003) while pointing out the persuasive and manipulative nature of interpersonal metadiscourse (interactional in Hyland's model) stated that interpersonal metadiscourse is very important in the construction of text which appears attractive, logical and convincing to the reader. Hence, the findings of the research suggest that the native and non-native English newspapers editorialists used interactional metadiscourse markers to make their writings more convincing and more appealing.

Findings show that the hedges and engagement markers are most frequent in both corpora. Among the interactional resources, booster and attitude markers are thought to have a convincing and manipulative function. Their presence in both the corpora shows that these items function as convincing and manipulative strategies in the editorials. Few examples have been discussed below which are found in native and non-native editorials.

Sometimes they will learn by trial and error (Dawn, 1 March 2019).

Sometimes Border Patrol makes large (State of Arizona, 11 April 2019).

This is terrorism and nothing else that nobody could and should tolerate. It must be rooted out forthwith (The Daily Mirror, 11 April 2019). 
Lawmakers should insist on reading the entire report (Washington Post, 18 April 2019).

According to the study proposed by Hyland (2005), attitude pointers furnish an opening for authors to indicate an assumption of common values, attitudes and responses to substance, by this means they describe a situation that brings readers into a state where arouse the concept of consequences of the agreement. So it is considered to be tough and readers are not able to disagree. In this manner, these devices help authors in completing their foremost objectives in the credible writings i.e., encouraging their readers. Few examples have been discussed below which are found in native and non-native editorials.

Unfortunately, this sad story doesn't end here (Hindustan Time, 22 April, 2019)

Unfortunately, there's plenty of evidence that the president can't be taken at his word when he says that the report is a "complete and total exoneration" of wrongdoing (The New York Time, 18 April, 2019).

I sought the thoughts of a retired international journalist whose opinion is usually worthy, knowing his distaste for Pilger (The New Zealand Harald, 17 March 2019).

Forced marriage is when the bride, groom (or both) don't want to get married but are pressured into it, usually by their families (Pakistan Observer, 20 March 2019)

The results of the research, therefore, indicate that both native and nonnative editorialists are cognizant of the convincing and manipulative power of these metadiscourse devices that is why they attach prime importance to them in their writings. As a result, one might be accomplished that frequent consumption of attitude indicators is projected as an innate representation of commentaries genre.

The outcomes of the research also reveal an interesting difference between the two sets of writers in the editorial genre. There is a significant and clear difference between native and non-native editorials in the use of hedges. Non-native English editorials contain fewer hedges than native English editorials which showed a weakening of arguments because hedges show a weakening of a claim through an unambiguous qualification of the writer's promise to display uncertainty (Hyland, 2005, 2007) and show that facts are presented as a judgment rather than qualified facts and figures (Hyland, 1998b). Hyland (1994: 241) opposes that in persuasive writing, hedges are an 
important means of both supporting the writer's position and building writerreader relationships. Few examples have been discussed below which are found in native and non-native editorials.

It is clear that the CJI ought not to have presided over the special Bench that took up the matter that concerned himself (The Hindu, 7 Mach 2019).

It is clear that through the AFRO and the other Black Press members' amplification of racial injustices, the Black community began to force the majority to recognize the entitlements they could no longer negate based upon race (Afro American, 10 April 2019).

The native English editorialists heavily overuse hedges by comparison with their non-native counterpart. It may be because of rhetorical conventions which are use by two sets of writers. In the nutshell, native English editorialists are found more appealing and polite to their reader than non-native English editorialists because of the fact presented thorough booster.

\section{CONCLUSION}

The current research showed that frequencies metadiscourse markers were quite frequent in the native English editorials compared to non-native English newspaper editorials. Findings of the study concluded that there are differences between native and non-native varieties of English in the use of interactional metadiscourse markers. Frequencies of main and subcategories of interactional metadiscourse vary in different Englishes as the study revealed that native editorialists used more interactional markers than their counterpart. The study also revealed that there are differences and similarities between native and non-native English regarding the use of markers. There were certain markers which were used by native but not by the non-native or vice-versa. The thing which becomes very important to point out that is the frequencies of the markers. Although the markers were similar in both varieties there was a significant variation among their use. For instance, findings of the research showed that use of self-mention, hedges and boosters are different across native and non-native editorials which pointed out linguistics variations across native and non-native cultures. It can be stated that similarities and differences are because of cultural differences between native and non-native editorials. 
On the whole, the study indicated that metadiscourse plays a significant and vital role in the construction and organization of persuasive strategies in any text. The study indicated that interactional markers played an important role in maintaining the link between reader and writer as it is indicated through attitude markers in both varieties. The study as contrastive research took a step towards the cross-linguistic analysis of two varieties of English within the same genre. It is hoped that it would play a vital role in teaching second and foreign languages. It would be beneficial for the learners and teachers to analyze and identify linguistic variation in the English language. There is considerable potential in this area for future research. The relatively small number of the analysed editorials was one of the limitations of the study. Other studies with larger samples could be applied to be certain about the validity of these findings.[rgt]

\section{REFERENCES}

Ansary, H., \& Babaii, E. (2009). A cross-cultural analysis of English newspaper editorials: a systemic-functional view of text for contrastive rhetoric research. RELCJournal, 40(2), 211-249.

Bhatia, V. (1993). Language use in professional settings. Applied Linguistics and Language Study). Longman.

Connor, U. (1996). Contrastive rhetoric: Cross-cultural aspect of second-language writing. Cambridge University Press.

Crismore, A. (1984). The rhetoric of textbooks: Metadiscourse. Journal of Curriculum Studies, 16(3), 279-296.

Crismore, A., Markkanen, R., \& Steffensen, M. S. (1993). Metadiscourse in persuasive writing: A study of texts written by American and Finnish university students. Written Communication, 10(1), 39-71.

Dafouz, E. (2003). Metadiscourse revisited: A contrastive study of persuasive writing in professional discourse. Estudios Ingleses de la Universidad Complutense, 11, 29-52.

Fowler, R. (1991). Language in the news: Discourse and ideology in the press. London: Routledge. 
Fuertes-Olivera, P. A., Velasco-Sacristán, M., Arribas-Baño, A., \& SamaniegoFernández, E. (2001). Persuasion and advertising English: Metadiscourse in slogans and headlines.Journal of Pragmatics, 33(8), 1291-1307.

Ghahremani Mina, K., \& Biria, R. (2017). Exploring Interactive and Interactional Metadiscourse Markers in Discussion Sections of Social and Medical Science Articles. International Journal of Research in English Education, 2(4), 11-29.

Harris, Z. S. (1959). The transformational model of language structure. Anthropological linguistics, 27-29.

Hyland, K. (1994). Hedging in academic writing and EAF textbooks. English for Specific Purposes, 13(3), 239-256.

Hyland, K (1998a). Persuasion and context: The pragmatics of academic metadiscourse. Journal of Pragmatics, 30, 437-455.

Hyland, K. (1998b). Boosting, hedging and the negotiation of academic knowledge. Text-Interdisciplinary Journal for the Study of Discourse, 18(3), 349-382.

Hyland, K. (1999). Talking to students: Metadiscourse in introductory coursebook. English for Specific Purposes, 18(1), 3-26.

Hyland, K. (2000). Disciplinary Discourses: Social Interactions in Academic Writing. Longman.

Hyland, K (2001). Humble servants of the discipline? Self-mention in research articles. English for Specific Purposes, 20, 207-226.

Hyland, K. (2004). Disciplinary discourses, Michigan classics ed.: Social interactions in academic writing. University of Michigan Press.

Hyland, K. (2005). Metadiscourse: Exploring interaction in writing. Continuum.

Hyland, K. (2007). Genre pedagogy: Language, literacy and L2 writing instruction. Journal of Second Language Writing, 16(3), 148-164.

Hyland, K. (2010). Metadiscourse: Mapping interactions in academic writing. Nordic Journal of English Studies, 9(2), 125-143.

Kaplan, R. B. (1966). Cultural thought patterns in inter-cultural education. Language Learning, 16 (1), 1-20.

Kuhi, D., \& Mojood, M. (2012). A contrastive study of metadiscourse in English and Persian editorials. The Journal of Applied Linguistics, 5(1).

Mauranen, A. (1993). Contrastive ESP rhetoric: Metatext in Finnish-English economics texts. English for Specific Purposes, 12(1), 3-22. 
Moreno, A. I. (1997). Genre constraints across languages: Causal metatext in Spanish and English RAs. English for Specific Purposes, 16(3), 161-179.

Milne, E. (2008). The Pragmatic Role of Textual and Interpersonal Metadiscourse Markers in the Construction and Attainment of Persuasion: A CrossLinguistic Study of Newspaper Discourse. Journal of Pragmatics, 40(1), 95113.

Mur-Dueñas, P. (2011). An intercultural analysis of metadiscourse features in research articles written in English and Spanish. Journal of Pragmatics, 43(12), 3068-3079.

Shahid, M. I., Qasim, H. M., \& Hasnain, M. (2020). A cross-linguistic study of metadiscourse in English and Urdu newspaper editorials. Corporum: Journal of Corpus Linguistics, 3(1), 33-56.

Siddique, A. R., Mahmood, M. A., \& Iqbal, J. (2018). Metadiscourse analysis of Pakistani English newspaper editorials: A corpus-based study. International Journal of English Linguistics, 8(1), 146-163.

Valero-Garcés, C. (1996). Contrastive ESP rhetoric: Metatext in Spanish-English economics texts. English for Specific Purposes, 15(4), 279-294. 